\title{
THE PROKINETIC EFFECT OF ITOPRIDE, A COMPARATIVE STUDY WITH METOCLOPRAMIDE
}

\author{
Elsayed M. Kamel, Hassan A .Shabayek., Fatma A. Aly, and Reham I. Elgarhi
}

Department of Clinical Pharmacology, Faculty of Medicine, Zagazig University

\begin{abstract}
The motor function of GIT can be modulated by prokinetics or myorelaxant drugs depending on the nature of the disorder. There is a frequent need for facilitation of gastric emptying in treatment of functional dyspepsia. Among prokinetic drugs used there are compounds belonging to cholinergic and adrenolytic classes. In addition, drugs having affinity for serotonin, motilin and opioid receptors, also participate in alleviating delayed gastric emptying. Itopride is a prokinetic that acts via blocking $\mathrm{D}_{2}$ receptors in addition to inhibition of choline esterase. Metoclopramide prokinetic effect on the other hand is mediated through $\mathrm{D}_{2}$ receptor blockade. This study was designed to investigate the effect of the two prokinetic drugs (itopride and metoclopramide) on the motility of different parts of GIT.

The results of the present work demonstrated that both itopride and metoclopramide produced significant increments in the amplitude of contraction of fundus stomach of rats, pylorus, jejunum and colon of rabbit in a concentration dependent manner, It was also proved that itopride is more potent as a prokinetic on these parts of GIT which is evident by the low ED50 of itopride compared to that of metoclopramide. In conclusion, itopride is preferred as a prokinetic than metoclopramide because it has higher potency in addition to acceleration of upper and lower GIT motility.
\end{abstract}

\section{INTRODUCTION}

The pathogenesis of functional dyspepsia is complex and not fully recognized. A lot of medications that mainly modulate secretory and motor function of GIT are used in the treatment of this disease. The introduction of new drugs particularly those inhibiting gastric secretion like proton pump inhibitors has been an undoubtable progression in attenuating the symptoms of the disease (Tack and Lee, 2005). The motor function in GIT can be modulated by either myorelaxant or prokinetic drugs depending on the nature of the disorder. There is a frequent need for facilitation of gastric emptying in treatment of functional dyspepsia (Ghosh et al., 2008). Among prokinetic drugs there are distinguished compounds from cholinergic and adrenolytic drugs demonstrating affinity for serotonin, motilin, opioid receptors and many other groups that participate in alleviating such disorder (Tonini et al., 1999).

The group of $5 \mathrm{HT}_{4}$ agonist was commonly used in the treatment of functional dyspepsia. They facilitate release of acetylcholine ( $\mathrm{ACh}$ ) from cholinergic nerve endings that accelerates GIT motility mainly in its upper segment (Tonini et al., 2003). Unfortunately, these drugs simultaneously affect potassium ion transport in cardiac muscle which can induce ventricular arrhythmias and accordingly these drugs (cisapride and tegaserod) have been withdrawn because of their life threatening cardiovascular 
events. However, some $5 \mathrm{HT}_{4}$ receptor agonists are still safely used (mosapride) (Tonini et al., 1999).

Metoclopramide is another prokinetic drug which facilitates gastric emptying via blocking $\mathrm{D}_{2}$ receptors and removing the inhibitory effect of dopamine and other adrenergic substances on the myenteric cholinergic activity (Lee and Kuo, 2010; Eras et al., 2013).

Itopride is a new prokinetic agent that was recently introduced for treating various GIT motility disorders via anticholinesterase activity as well as $\mathrm{D}_{2}$ receptors antagonistic activity (Satapathy, 2003). Itopride increases gastric motility, increases the lower esophageal sphincter pressure, accelerates gastric emptying and improves gastroduodenal coordination (Kusano et al., 2011).

It is well known that some prokinetics particularly those crossing the blood brain barrier and blocking $\mathrm{D}_{2}$ receptors centrally often induce extrapyramidal manifestations like tardive dyskinesia and neuroleptic syndrome that greatly limit their use in GIT disorders for long period and restricted only for short-term therapy (Palermo-Neoj, 1997). Since itopride does not cross the blood brain barrier thus does not exhibit and is devoid of the aforementioned adverse effects (Camelleri, 2009).

As metoclopramide can produce serious effects on CNS that make its use as a prokinetic and antiemetic (Pasrisha et al., 2006) is risky in addition its prokinetic effect is restricted mainly on upper segment of GIT (Eras et al., 2013). Itopride which has multiple mechanisms of action may be useful and safe prokinetic since it can act on upper and lower GIT segments. Therefore, the aim of this study was to investigate the prokinetic effect of both itopride and metoclopramide on the different parts of GIT isolated from experimental animals in a trial to identify if there is any difference between their effects.

\section{MATERIALS AND METHODS}

\section{Drugs and Chemicals:}

Each of itopride hydrochloride, powder (Eva pharm., Cairo, Egypt) and metoclopramide hydrochloride, (Primperan) ampoules (Memphis Co., Cairo, Egypt) was dissolved in distilled water and diluted to be used in umol/L concentration. Each of potassium dihydrogen phosphate $\left(\mathrm{KH}_{2} \mathrm{PO}_{4}\right)$, potassium chloride $(\mathrm{KCl})$ powder, sodium chloride powder, glucose powder, sodium bicarbonate powder was obtained from El Nasr Pharmaceutical Co., Abo-Zaabal , Cairo, Egypt. Each of glucose powder, calcium chloride powder, sodium dihydrogen phosphate powder, magnesium sulphate powder was obtained from El Gomhoreya Co., Cairo, Egypt.

\section{Experimental design}

Dose-response curves for both itopride and metochlopramide were obtained from in-vitro experiments on different isolated tissues (rat's fundus, and rabbit's pylorus, jejunum and colon). $\mathrm{ED}_{50}$ for each drug was determined to be used in the comparison between the two drugs. 
Experiments on isolated rat's fundus and rabbit's pylorus strips were conducted according to Perry (1970) and Gosh, (1971), respectively.

Experiments on isolated rabbit's jejunum and colon were conducted according to Fatt (1950) and Gosh (1971).

Statistical analysis of data: All data were analyzed using statistical program for social science (SPSS) mainly by one-way ANOVA test for windows version 10. The data were represented as means \pm SEM of six experiments for each drug.

\section{RESULTS}

\section{Effect of itopride and metoclopramide on contractility of fundus of rat's stomach:}

The results of the present study demonstrated that itopride in ascending concentrations $(5,10,20,40,80 \mu \mathrm{mol} / \mathrm{l})$ produced significant $(\mathrm{p} \leq 0.05)$ concentrationdependent increments in the amplitude of fundus contraction (Fig. 1A). Also, metoclopramide in ascending concentrations $(10,20,40,80,160 \mu \mathrm{mol} / \mathrm{l})$ produced significant $(\mathrm{p} \leq 0.05)$ increments in the amplitude of fundus contraction (Fig.1B)

As shown from dose-response curves for both itopride and metoclopramide, it was noticed that itopride is more potent than metoclopramide and this is evident by the low $\mathrm{ED}_{50}$ of itopride compared to metoclopramide. The ED50 of itopride was 17.9 $\mu \mathrm{mol} / 1$ whereas of metoclopramide it was $59 \mu \mathrm{mol} / \mathrm{l}$ (Fig. 1C)

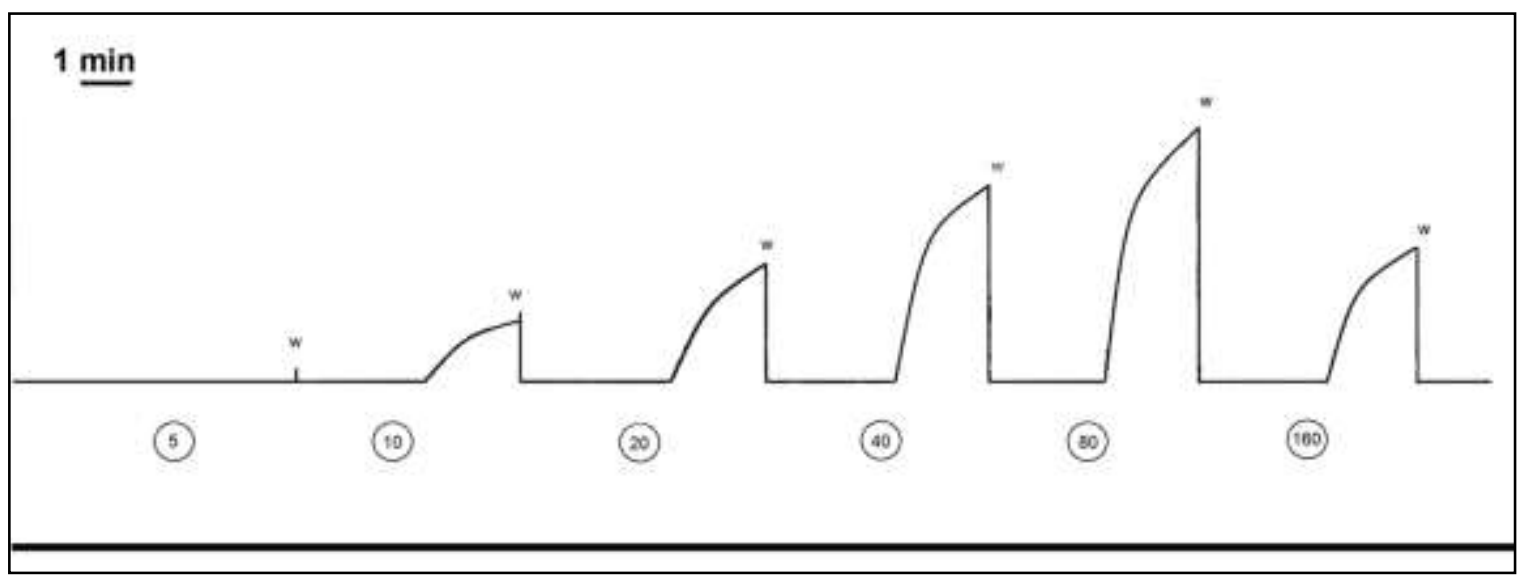

Fig. 1A: Effect of itopride hydrochloride $(5-80 \mu \mathrm{mol} / \mathrm{L})$ on contractility of isolated perfused rat's fundus. 


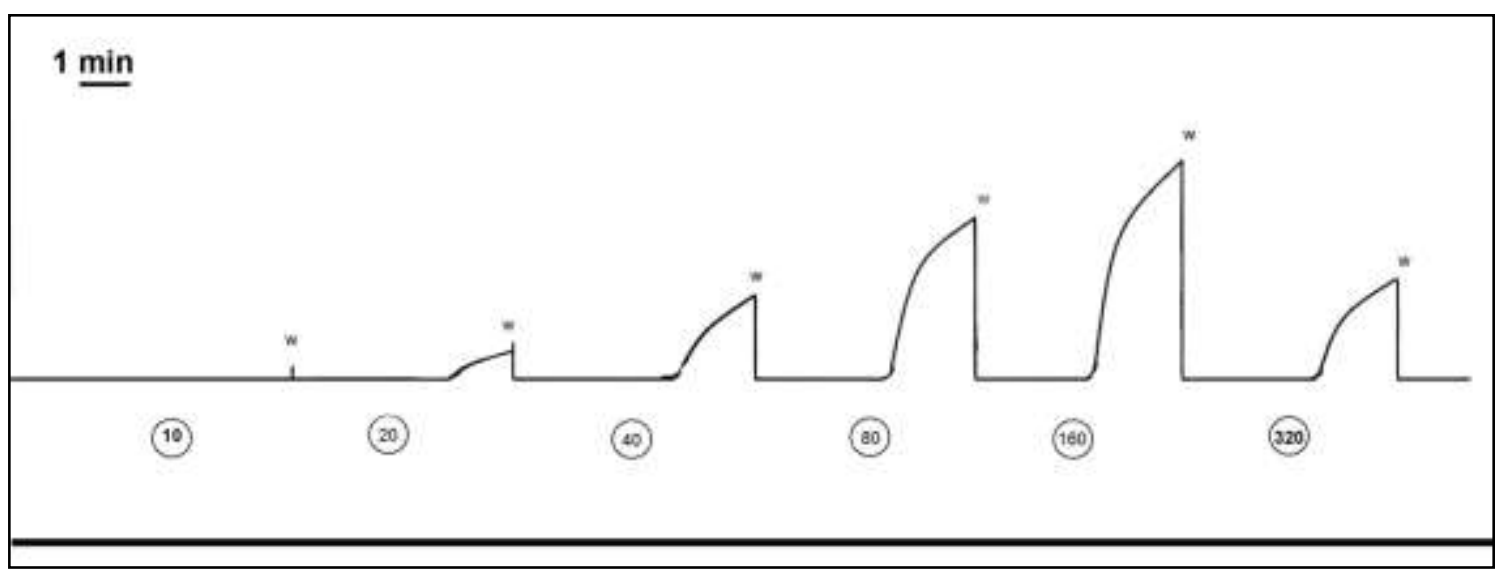

Fig. 1B: Effect of metoclopramide $(10-160 \mu \mathrm{mol} / \mathrm{L})$ on contractility of isolated perfused rat's fundus.

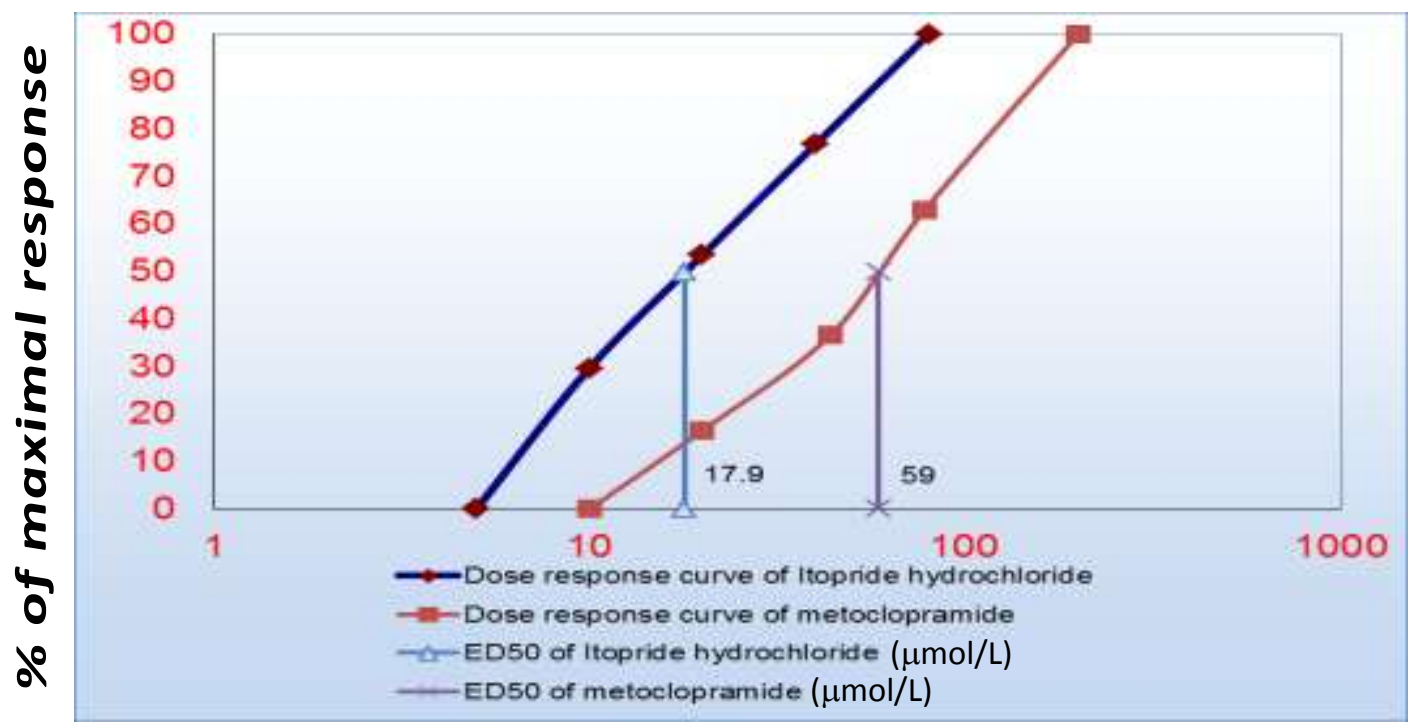

Fig. 1C: Comparison between dose response curves of itopride hydrochloride and metoclopramide on isolated fundus of rat's stomach.

\section{Effect of itopride and metoclopramide on contractility of pylorus of rabbit's stomach:}

The results of the current work showed that itopride in ascending concentrations $(0.5,1,2,4,8 \mu \mathrm{mol} / 1)$ produced significant $(\mathrm{p} \leq 0.05)$ concentration-dependent increase in the amplitude of pyloric contraction. Similarly, metoclopramide in ascending concentrations $(4,8,16,32,64 \mu \mathrm{mol} / \mathrm{l})$ produced significant $(\mathrm{p} \leq 0.05)$ contraction. As revealed from the results of this study, it could be observed that itopride is more potent than metoclopramide in inducing contraction of rabbit's pylorus. This high potency of itopride is evidenced by the low ED50 $(1.754 \mu \mathrm{mol} / \mathrm{l})$ while that of metoclopramide was (12. $393 \mu \mathrm{mol} / \mathrm{l})$ (Fig. $2 \mathrm{~A}, \mathrm{~B}$ and C). 


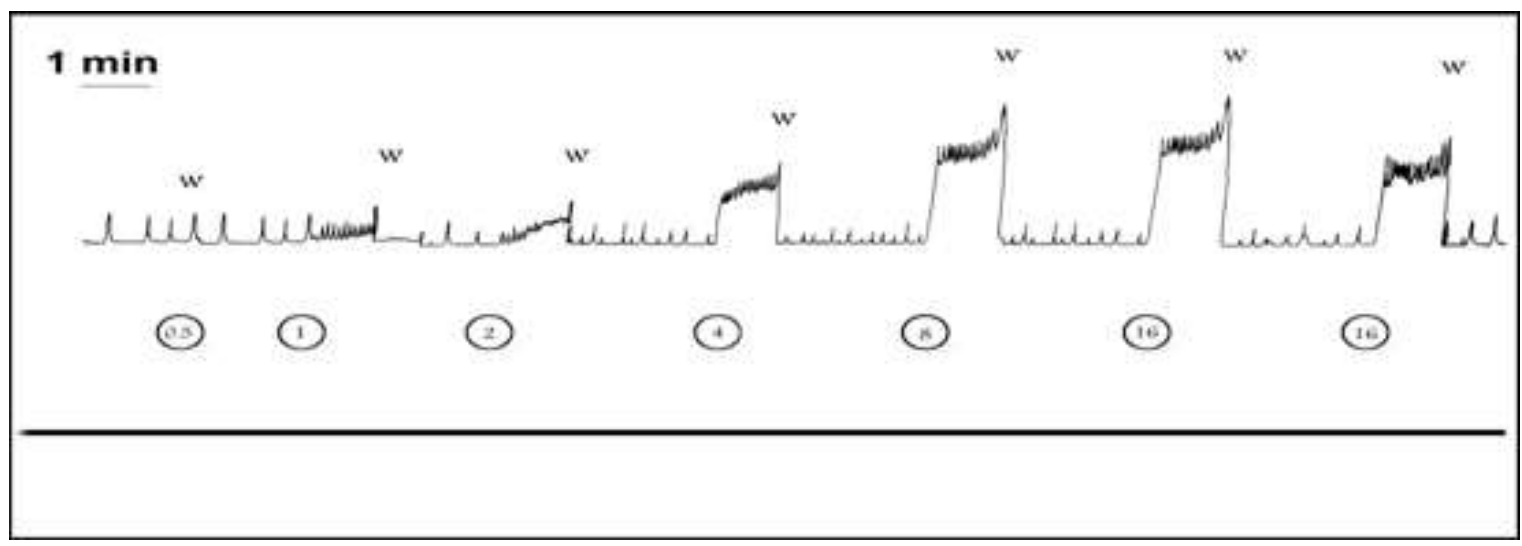

Fig. 2A: Effect of itopride hydrochloride $(0.5-16 \mu \mathrm{mol} / \mathrm{L})$ on contractility of isolated perfused rabbit's pylorus.

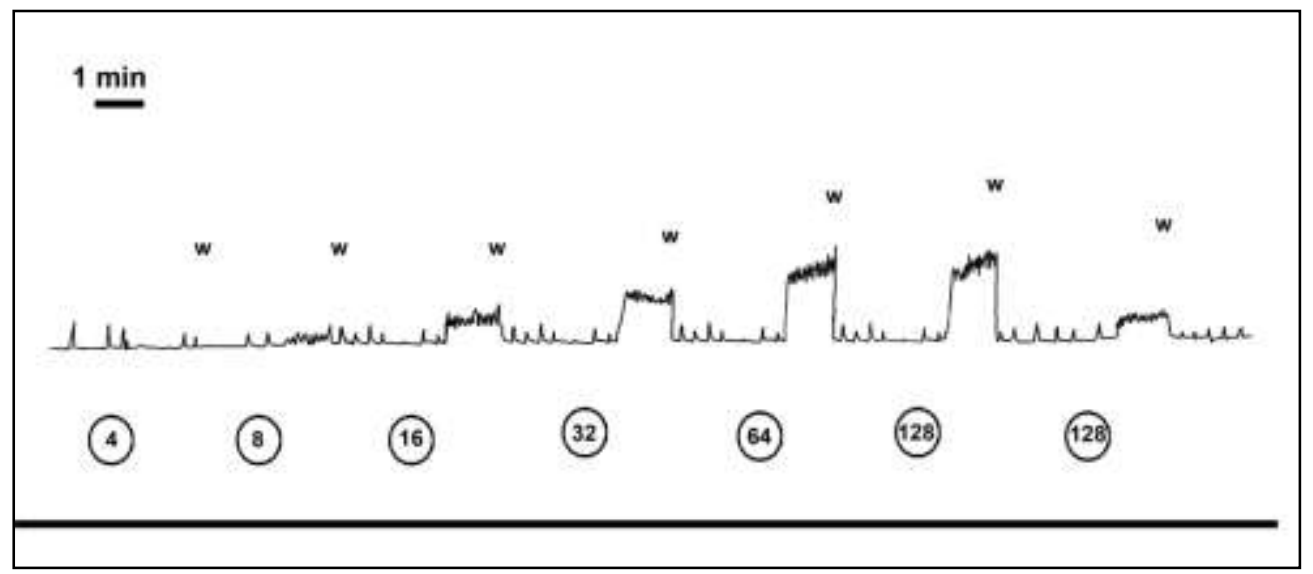

Fig. 2B: Effect of metoclopramide $(4-128 \mu \mathrm{mol} / \mathrm{L})$ on contractility of isolated perfused rabbit's pylorus.

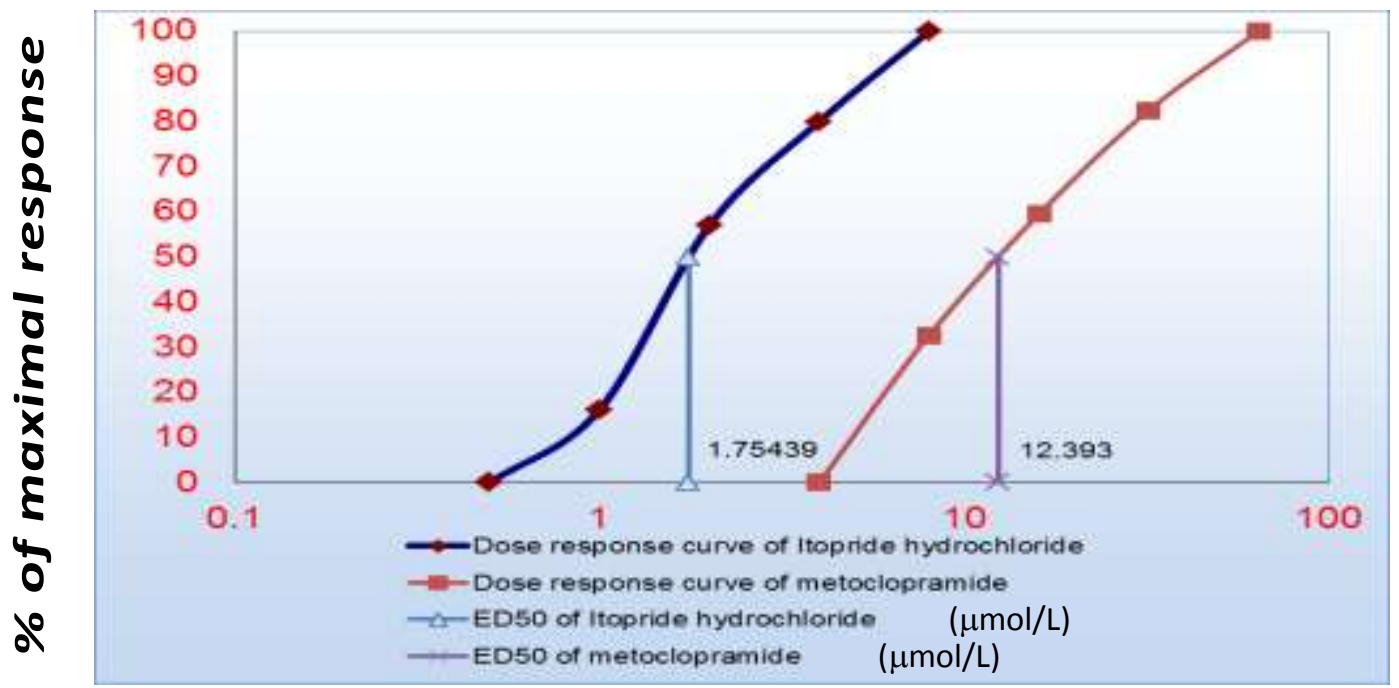

Fig. 2C: Comparison between dose response curves of itopride hydrochloride and metoclopramide on isolated pylorus of rabbit's stomach

Effect of itopride and metoclopramide on contractility of rabbit's jejunum: 
As observed from the results of the present work, itopride in ascending concentration $(0.05,0.1,0.2,0.4,0.8,1.6 \mu \mathrm{mol} / \mathrm{l})$ produced significant $(\mathrm{p} \leq 0.05)$ concentration-dependent increase in the amplitude of jejunal contraction. It was also revealed that metoclopramide produced significant increase $(\mathrm{p} \leq 0.05)$ in jejunal contraction which was concentration-dependent ( $0.2,0.4,0.8,1.6,3.2,6.4 \mu \mathrm{mol} / 1$ ) (Fig. 3A and B).

The dose - response curves of the two given drugs demonstrated that itopride is highly potent compared to metoclopramide and this was evidenced by the low ED 50 of itopride $(0.166 \mu \mathrm{mol} / \mathrm{l})$ where as that of metoclopramide was $(0.704 \mu \mathrm{mol} / \mathrm{l})$ (Fig. 3C).

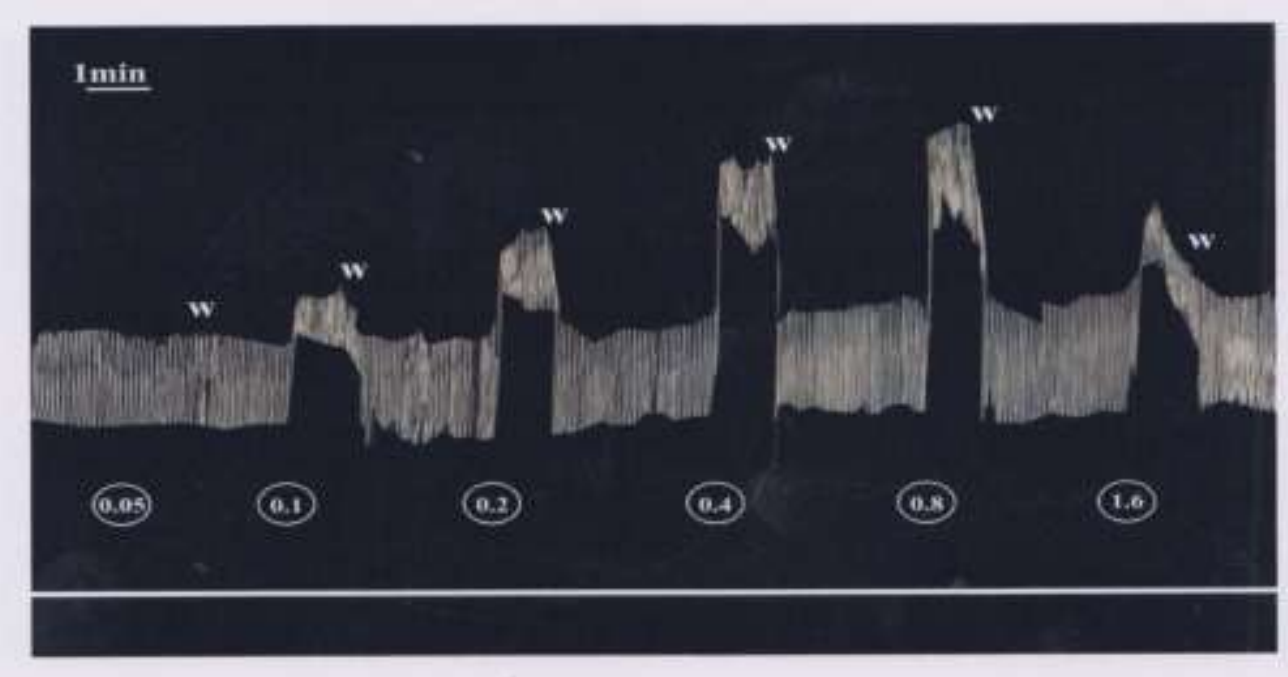

(Fig. 3A): Effect of itopride hydrochloride $(0.05-1.6 \mu \mathrm{mol} / \mathrm{L})$ on contractility of isolated perfused rabbit's jejunum.

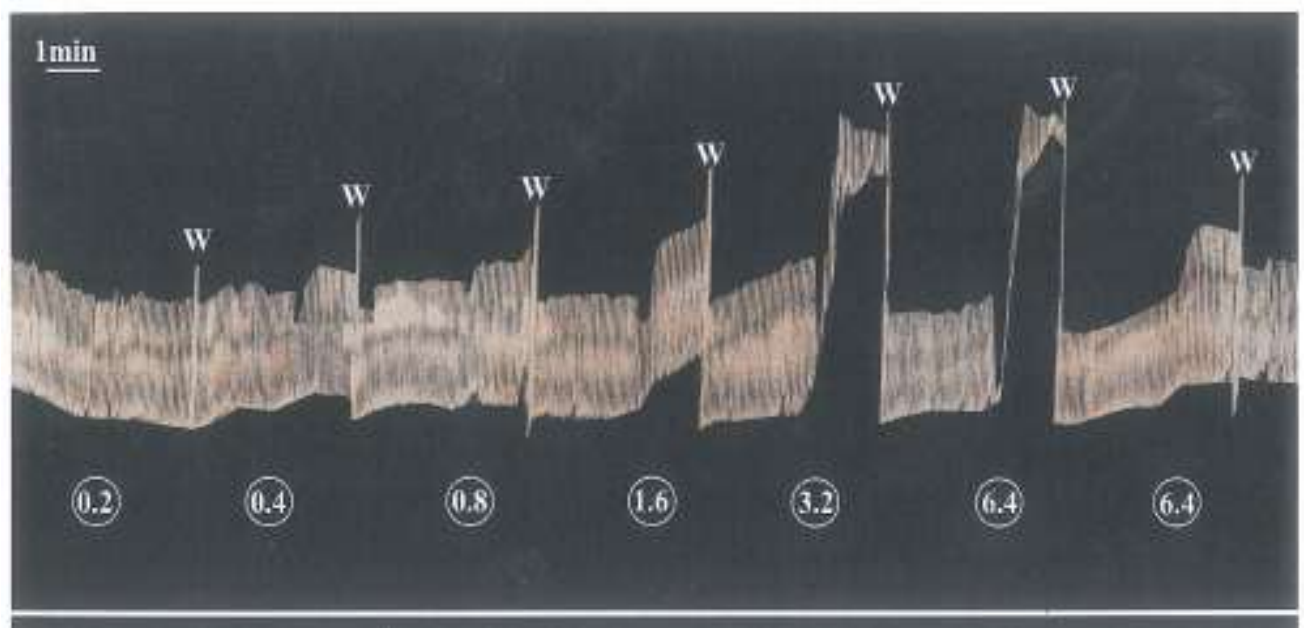

(Fig. 3 B): Effect of metoclopramide $(0.2-6.4 \mu \mathrm{mol} / \mathrm{L})$ on contractility of isolated perfused rabbit's jejunum. 


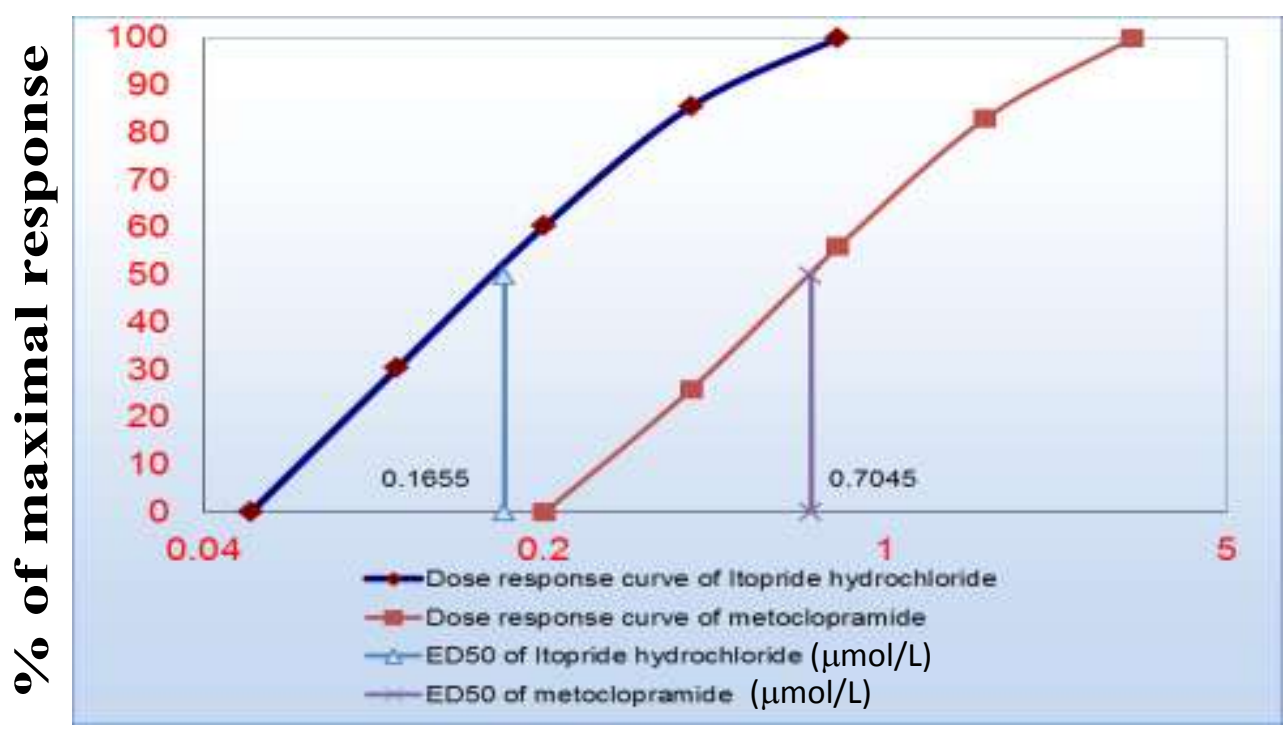

(Fig. 3C): Dose response curves of itopride hydrochloride and metoclopramide on isolated rabbit's jejunum.

\section{(1) Effect of itopride and metoclopramide on contractility of rabbit's colon:}

It was noticed that itopride in graded concentrations $(0.05,0.1,0.2,0.4,0.8,1.6$ $\mu \mathrm{mol} / \mathrm{l})$ produced significant increases $(\mathrm{p} \leq 0.05)$ in a concentration-dependent manner in the amplitude of colonic contraction. Similarly, metoclopramide did produce significant $(p \leq 0.05)$ increases in the amplitude of colonic contraction. The increase in contraction was in a concentration-dependent manner (Fig. 4A and B).

Comparing the dose-response curves of the two given drugs demonstrated that itopride is greatly potent in induction of colonic contraction than metoclopramide. This higher potency was evidenced by the low $\mathrm{ED}_{50}$ of itopride $(0.175 \mu \mathrm{mol} / \mathrm{l})$ while that of metoclopramide was $(17.15 \mu \mathrm{mol} / \mathrm{l})$ (Fig. 4C).



Fig. 4A: Effect of itopride hydrochloride $(0.05-1.6 \mu \mathrm{mol} / \mathrm{L})$ on contractility of isolated perfused rabbit's colon. 


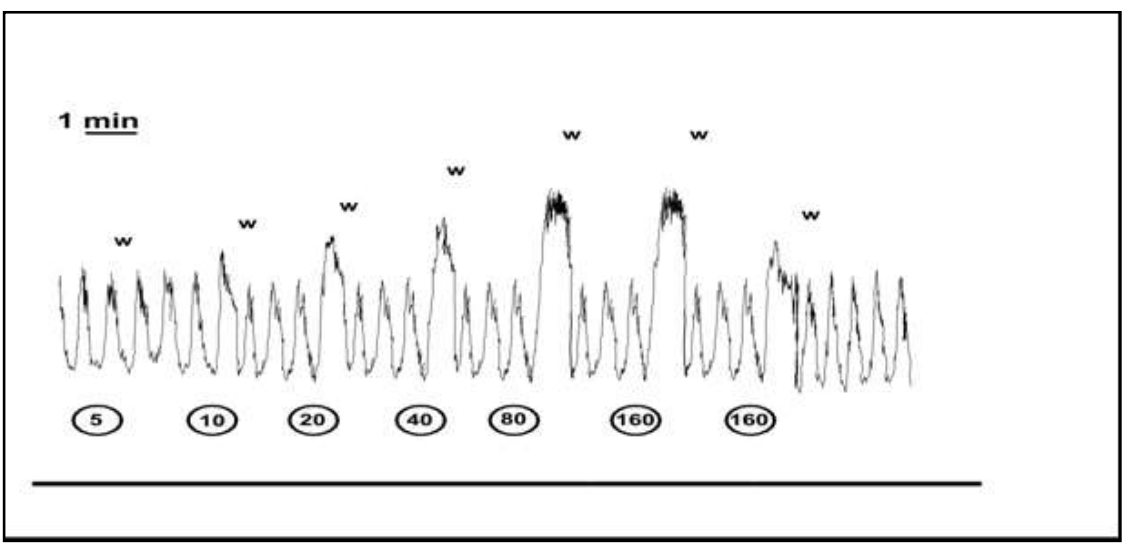

Fig. 4B: Effect of metoclopramide $(5-160 \mu \mathrm{mol} / \mathrm{L})$ on contractility of isolated perfused rabbit's colon.

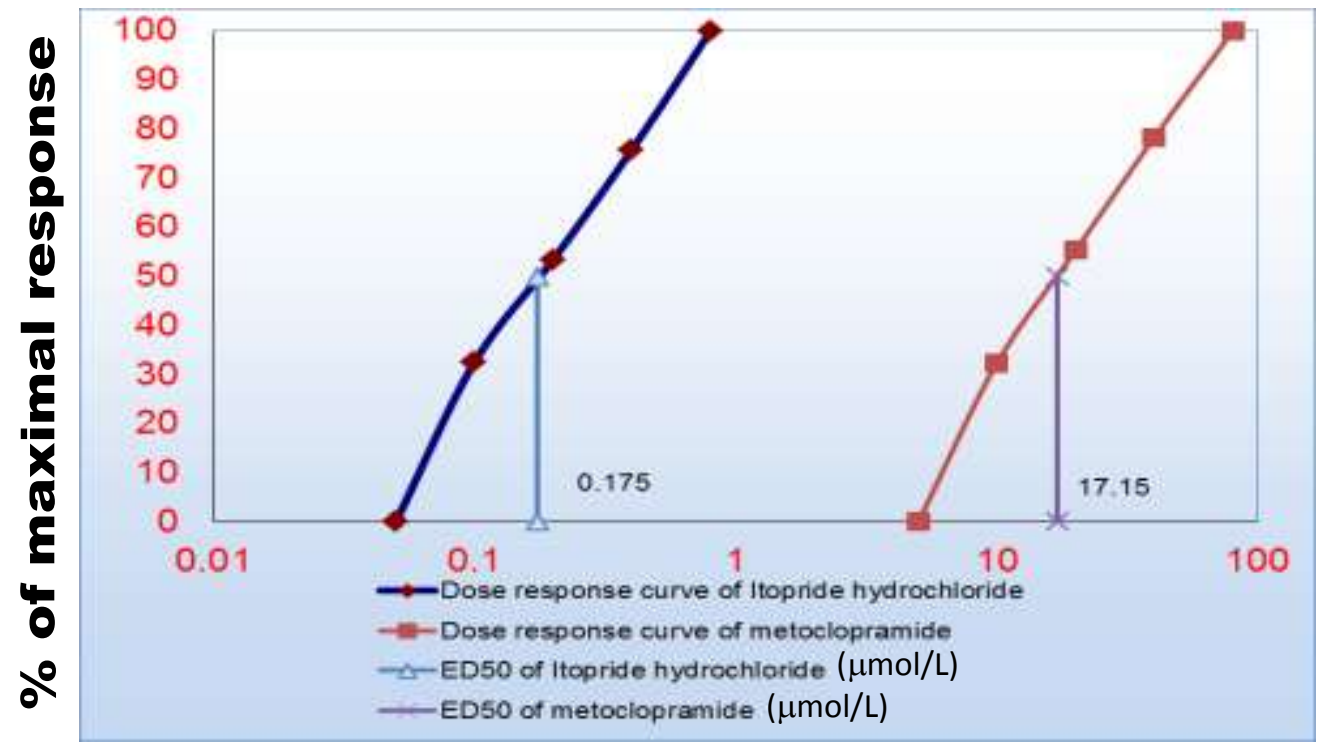

Fig. 4C: Comparison between dose-response curves of itopride hydrochloride and metoclopramide on isolated rabbit's colon.

\section{DISCUSSION}

Prokinetic agents are commonly used in treatment of patients with functional dyspepsia. Functional dyspepsia is a medical condition characterized by chronic or recurrent upper abdominal pain, fullness bloating, belching and nausea or heart burn (Veldhuyzen et al., 2001).

Clinically, prokinetic agents such as domperidone, cisapride, and mosapride are often used to treat patients with functional dyspepsia, however, itopride is commonly used given the concern of safety compared to other prokinetic agents but its potency needs clarification (Hiyama et al., 2007; Huang et al., 2012).

Itopride is a prokinetic acts via stimulation of release of ACh by antagonizing dopamine ( $\mathrm{D}_{2}$ receptors) on postsynaptic cholinergic neurons. In addition, it has an anticholinesterase activity (Hyun et al., 2008). This work was designed to study the 
effect of itopride on small bowel and colonic motility in comparison with the standard prokinetic metoclopramide .

The results of the present study demonstrated that itopride is more potent than metoclopramide in stimulating motility of the rat's stomach fundus. This finding was proved by the lower $\mathrm{ED}_{50}$ of itopride compared to that of metoclopramide.

Regarding the significant stimulant effect of itopride on fundic gastric motility the finding of this study is in consistence with the results of Tsuboushi et al. (2003) and Holtmann et al. (2006) who reported that itopride has a stimulant action on fundic gastric motility in both experimental animals and human.

In contrast to the finding of the current work, Mine et al. (1997) and Tsuboushi et al. (2003) showed that cisapride and mosapride which act through stimulation of $5 \mathrm{HT}_{4}$ receptors are more potent than itopride on the fundic gastric gland. This contradiction between our findings and those of Mine et al. (1997) and Tsuboushi et al. (2003) could be due to the difference in methodology and species of the animal utilized in study, since the previous work was performed on conscious dog and the drugs used were injected intraduodenally, whereas in the current study rat was utilized and the study was done in-vitro.

As regard the effects of itopride on the pyloric part of rabbit's stomach, it was evident that itopride has a significant stimulant action which is greater than that of metoclopramide. The more potent stimulant effect of itopride compared to metoclopramide was proved by the low $\mathrm{ED}_{50}$ of the former compared to the latter.

The stimulant effect of itopride on pylorus of rabbit's stomach as revealed by the findings of the present study is compatible with those of Iwanaga et al. (1990) who reported that itopride significantly increased the contraction force of the stomach and duodenum when used in conscious dog. However, the study of Iwanga et al. (1996) conflicts the results of the present work as they reported that itopride is weak compared to metoclopramide or domperidone. The controversy between the results of Iwanaga et al. (1996) and the findings of the present work seems to be due to different species of the animal used and method of stimulation of pyloric part of the stomach.

Similarly, itopride significantly increased the tone and amplitude of rabbit's jejunal contraction in-vitro. It was also observed that itopride has higher potency in comparison to metoclopramide which is evident by the low $\mathrm{ED}_{50}$ of itopride. This finding copes with the results of Miyashita et al., (1991) who stated that metoclopramide and domperidone when used as prokinetics in conscious dogs produced little effect on the small intestine compared to itopride. Again, our findings regarding the significant stimulant effect on rabbit's jejunal motility was confirmed by Tsubouchi et al. (2003) who reported that itopride increases the amplitude of longitudinal muscle and frequency of peristalsis in guinea pig ileum compared with other prokinetic drugs. Additionally, Iwanaga et al. (1993) demonstrated that itopride was found to stimulate intestinal contractility at a lower concentration than other prokinetics do in vitro.

Regarding the effect of itopride on colonic motility the results of the present work revealed that itopride has a significant effect in induction of colonic contraction while metoclopramide produce a lesser effect than itopride and this was proved by the 
low $\mathrm{ED}_{50}$ of itopride compared to metoclopramide. The prokinetic effect of itopride on colonic movement as revealed by our study was compatible with those of Hyun et al. (2008) who reported that itopride could significantly increase the frequency of peristaltic and segmental contraction in the proximal and distal colon in guinea pig. Furthermore, Hyun et al. (2008) attributed the stimulant effect of itopride on colonic motility to its anticholinesterase activity and consequent increase in ACh which directly stimulates $\mathrm{M}_{3}$ muscarinic receptors in GIT. Moreover, the results of the current work was in accordance with those of Buchheit and Duhl (1993), in another in-vitro experiments that revealed that itopride action on colon was observed at lower concentration compared to other prokinetics.

In a clinical comparative evaluation of the efficacy and tolerability of itopride and domperidone in patients with Non-ulcer Dyspepsia (NUD) showed that itopride is more efficient compared to domperidone in relieving the symptoms of NUD. Both drugs were tolerated, especially itopride that did not cause any remarkable rise of prolactin or changes in QT interval in the studied group (Prabha et al., 2004).

The role of itopride as a prokinetic all over the GIT wall as demonstrated in the present study can be explained on the basis of the dual action of itopride, where, it acts as dopamine antagonist and anticholinesterase as discussed by Tsubouchi et al. (2003), who reported that although stimulation of GIT motility by itopride is ascribed to activation of cholinergic drive based on $\mathrm{D}_{2}$ receptors blocking and cholinesterase inhibition, the stimulant action on colonic motility seems mainly due to anticholinesterase activity.

In fact $\mathrm{M}_{3}$ cholinoceptors exist on the smooth muscle layer of the whole GIT and ACh released from the enteric nerve ending stimulates the contraction of these muscles through $\mathrm{M}_{3}$ receptors (Sakurai-Yamashita et al, 1999 a, b), therefore, itopride was able to stimulate entire GIT parts from gastric antrum to the descending colon in contrast to metoclopramide which acts via $5 \mathrm{HT}_{4}$ receptor activation stimulating gastric motility at lower doses than colonic motility while itopride, that acts as anticholinesterase inhibitor, acts on both upper and lower GIT.

Finally, it could be concluded that itopride is a prokinetic on the upper and lower GIT which is mediated by its dual mechanism of action as $\mathrm{D}_{2}$ receptor antagonist and cholinesterase inhibitory action. These data will provide an experimental background for use of itopride in treatment of patients with constipation or other functional bowel disorder. Further experimental and clinical studies are required to confirm our result as itopride is a promising prokinetic with high potency and safety compared to other prokinetics particularly metoclopramide.

\section{REFERENCES}

Buchheit K-H and Buhl T. (1993): 5-HT receptor subtypes involved in the stimulatory effect of 5-HT on the peristaltic reflex in vitro. J Gastrointest Motil 5:49-55.

Camelleri M.(2009):Metoclopramide and tardive dyskinesia. Aliment. Pharmacol. Ther..(31):11-19. 
Eras Z., Oğuz S. and Dilmen U. (2013): Is metoclopramide safe for the premature infant? Eur Rev Med Pharmacol Sci. 17(12):1655-7.

Fatt P. (1950) : Electromotor action of acetyl choline at the motor end plate . J. Physiol 111, 408-422.

Ghosh A., Halder S., Mandal S., Mandal A., Pasu M., Dabholkar P., (2008): A valuable drug for managing functional dyspepsia. J.Indian Med. Assoc. 106:752754.

Gosh M. N. (1971): Isolated tissues preparation. Fundamentals of Experimental Pharmacology, chap.6, pp. 39-46.

Hiyama T., Yoshihara M., Matsuo K., Kusunoki H., Kamda T., Lito M., Tanaka S., Chayama K., Haruma K.(2007): Treatment of functional dyspepsia with serotonin agonists: a meta-analysis of randomized controlled trials. J Gastroenterol Hepatol. 22:1566-1570.

Holtmann G., Talley NJ.,Liebregts T., Adam P., Parrow C.(2006): A placebocontrolled trial of itopride in functional dyspepsia. N Engl J Med. 354:832-840.

Huang X, Bin Lv, Shuo Zhang, Yi-Hong Fan, Li-Na Meng. (2012):Itopride therapy for functional dyspepsia: A meta-analysis.World J. gastroenterol.18(48):73717377.

Hyun C. L. , Young G. K., Jung H. L. ,Hee S. K., Hyojin P.(2008): Effect of itopride hydrochloride on the ileal and colonic motility in guinea pig in vitro. Yonsei Med J.49 (3):472-478.

Iwanaga Y., Miyashita N., Morikawa K., Mizumoto A., Kandoy Y., Itoh Z.(1990): A novel water-soluble dopamine-2 antagonist with anticholinesterase activity in gastrointestinal motor activity . Comparison with domperidone and neostigmine Gastroenterology 99 (2): 401-408.

Iwanaga Y., Suzuki N., Kato KI., Kimura T., Morikawa K., Kato H .(1993): Stimulatory effects of HSR-803 on ileal motor activity, Jpn. J. Pharmacol. 62 (4):395-401.

Iwanaga Y., Miyashita N., Saito T., Morikawa K., Itoh Z. (1996): Gastroprokinetic effect of a new benzamide derivative itopride and its action mechanisms in conscious dogs. Jpn J. Pharmacol.71 (2):129-137.

Kusano M., Moki F. and Hosaka H, Shimyama Y., Kawamura O., Nagoshi A.(2011):Gastroptosis is associated with less dyspepsia, rather than a cause of dyspepsia , in Japanese persons. Intern Med.50 (7):667-671.

Lee A. and Kuo B. (2010): Metoclopramide in the treatment of diabetic gastroparesis. Expert. Rev. Endocrinol.Metab.5 (5):653-662.

Mine Y. , Yoshikawa T., Oku S., Nagai R., Yoshida N, Hosoki K.(1997): comparison of effect of mosapride citrate and existing 5- $\mathrm{HT}_{4}$ receptor agonists on gastrointestinal motility in vivo and in vitro. $\mathrm{J}$ pharmacol Exp. Ther. 283 (3):1000-1008.

Miyashita N., Iwanaga Y., Ohshita M., Morikawa K., Kato H.,Ito Y., Itoh Z., (1991): Organ specificity of contractile response to HSR-803, a new 
gastroprokinetic agent, on gastrointestinal motility in conscious dogs .J Gastrointest Motil.3:190.

Palermo-Neto ,J.(1997): Dopaminergic systems: dopamine receptors. Psychatric Clin North Am. 20:705-721.

Pasrisha PJ., Pehlivanov N.,SugumarA., Jankovic J.(2006):Drug insight: from disturbed motility to disordered movement- a review of clinical benefits and medicolegal risks of metoclopramide. Nat Clin Pract Gastrenterol Hepatol.(3):138-148.

Perry W.L.M (1970):Experiments with other smooth muscle preparation, the rat fundus strip, In Pharma. Exp. on isolated preparations. 2nd edition, Churchill Livingstone. Edinburgh, London and New York. p.88-91.

Prabha S., Hs D., Nutan D., Skalokhe, Spatil.(2004):Comparative evaluation of the efficacy and tolerability of itopride hydrochloride and domperidone in patients with non-ulcer dyspepsia. JAPI.52:626-628.

Sakurai Y., Yamashita K., Kasnematsu T., Taniyama K.(1999):localization of 5$\mathrm{HT}_{4}$ receptor in the human and the guinea pig colon.Eur J Pharmacol.383:281285.

Sakurai Y., Takada K., Takemura K., Yamashita K., Enjoji A., Kanematsu T., Taniyama K.(1999b):Ability of mosapride to bind to $5-\mathrm{HT}_{4}$ receptor in the human stomach.Jpn J Pharmacol.79:493-496.

SatapathyT (2003): Drug therapy of gastroesophaggeal reflux disease (GORD): focus on itopride hydrochloride. Indian Pract. 56:827-830.

Tack J. and Lee KJ.(2005):Pathophysiology and treatment of functional dyspepsia. J. Clin Gastroenterol.39:211-216.

Tonini M., Deponti F., Di Nacci A.,Crema F.(1999):cardiac adverse effects of gastrointestinal prokinetics, Aliment. pharmacol. Ther.(13):1585- 1591.

Tonini M., De Giorgio R. and Spelta V., Bassoti G., Di Nucci A., Anselmi A.(2003):5- $\mathrm{HT}_{4}$ receptors contribute to the motor stimulatory effect of levosulpride in guinea pig gastrointestinal tract. Dig.Liver Dis.(35):244-250.

Tsubouchi T., Saito T., Mizutani F., Yamauchi T., Iawanga Y.(2003):Stimulatory action of itopride hydrochloride on colonic motor activity in vitro and in vivo.J. Pharmacol Exp.Ther.306:787-793.

Veldhuyzen V. Z. SJ, Jones MJ, Verlinden M., Talley NJ.(2001): Efficacy of cisapride and domperidone in functional (nonulcer) dyspepsia: a metaanalysis. Am J Gastroenterol. 96:689-696. 


\section{تأثير الإيتوبريد المنشط لحركة الجهاز الهضمي: دراسة مقارنة مع الميتوكلوبراميد}

\section{السيد محمد كامل، حسن عبدالعزيز شبايك، فاطمة عطوة علي}

\section{قسم الفارماكولوجيا الإكلينيكيةـ كلية الطب جامعة الزقازيق}

أجري هذا البحث بغرض معرفة تأثثر الإيتوبريد (أحد الأدوية التي تسرع من حركة الجهاز الهضمي)

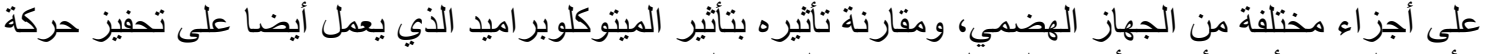

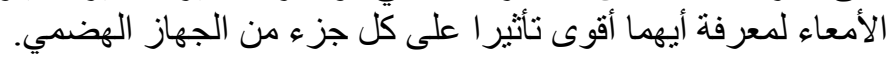

ولقد استخدم في هذه الدراسة r ا فأر ا و ب أرنبا وقد قسمت كالآتي:

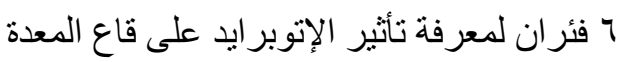

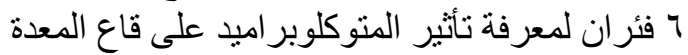

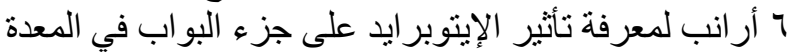

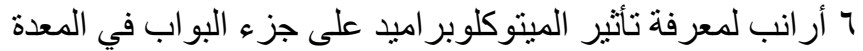

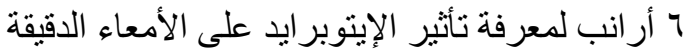

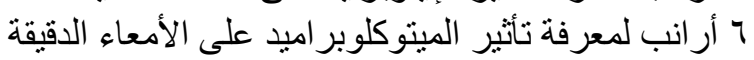

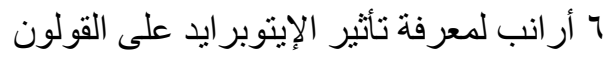

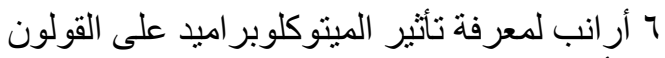

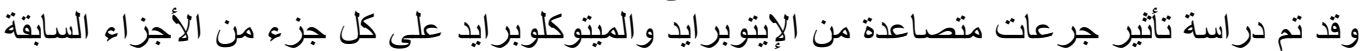

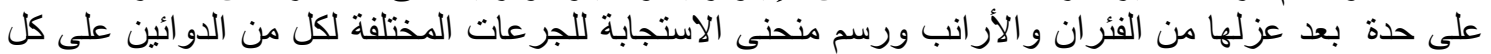

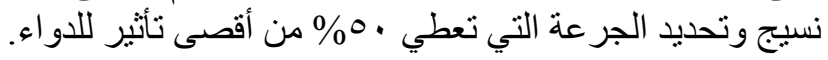

$$
\text { وقد وجد أن: }
$$

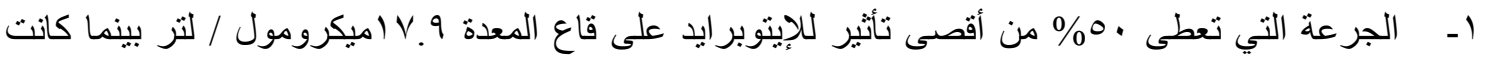



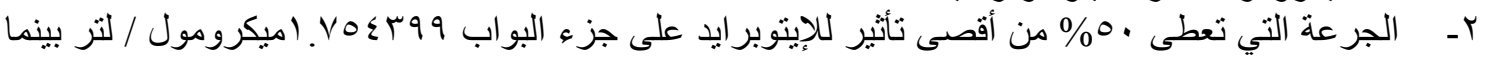

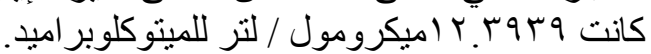

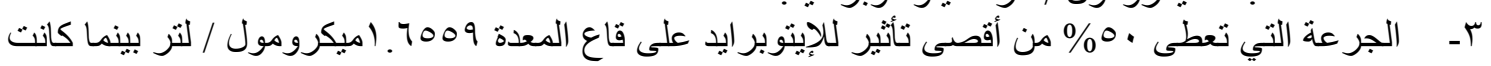

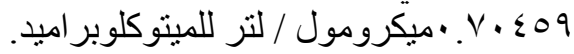



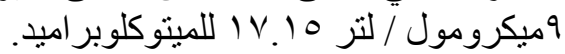

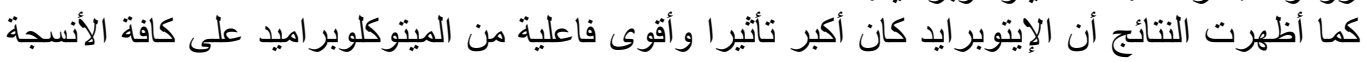
التي استخدت في هذه الدر اسة بمقارنة جر عات الأبر الدو ائين.

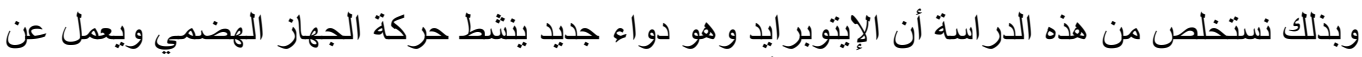

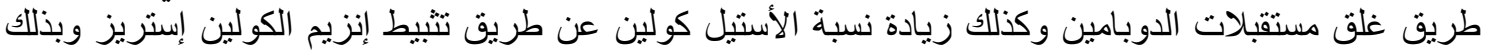

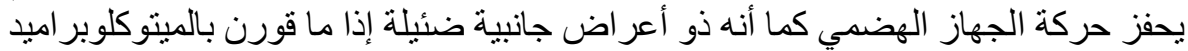

وزيادة على ذلك فإن الإيتوبرايد يساعد في علاج عسر الهضم الوظيفي حيث أنه أقوى تأثير ا وأقل في

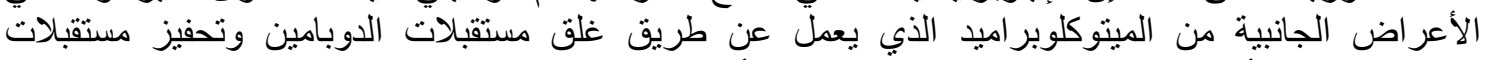

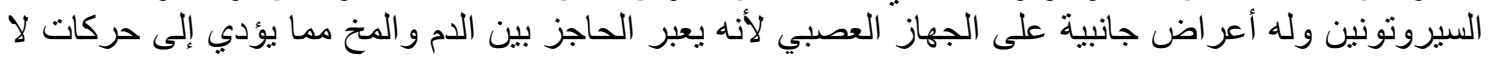
إر ادية لدى المريض لذللك ينصح باستخدام الإينوبر ايد كبديل آمن. 